\title{
PENGARUH KUALITAS PRODUK, KUALITAS LAYANAN, DAN SUASANA TOKO TERHADAP KEPUTUSAN PEMBELIAN PRODUK MINUMAN CHATIME DI MALL CIPUTRA, JAKARTA BARAT
}

\author{
Angelika $^{1}$, Yenny Lego ${ }^{2}$ \\ ${ }^{1}$ Program Studi Manajemen, Fakultas Ekonomi dan Bisnis, Universitas Tarumanagara \\ Email: angelika.115170126@stu.untar.ac.id \\ ${ }^{2}$ Program Studi Manajemen, Fakultas Ekonomi dan Bisnis, Universitas Tarumanagara* \\ Email: yennyl@fe.untar.ac.id \\ *Penulis Korespondensi
}

Masuk : 02-08-2021, revisi: 15-08-2021, diterima untuk diterbitkan : 30-08-2021

\begin{abstract}
ABSTRAK
Tujuan dari penelitian ini adalah untuk menguji pengaruh kualitas produk, kualitas layanan, dan suasana toko terhadap keputusan pembelian produk minuman Chatime di mall Ciputra, Jakarta Barat. Sampel dari penelitian ini adalah 100 pelanggan Chatime di mall Ciputra. Metode purposive sampling digunakan dengan menyebarkan kuesioner secara online yang kemudian diolah menggunakan PLS-SEM. Hasil dari penelitian ini adalah Kualitas Produk dan Kualitas Layanan memiliki pengaruh yang positif dan signifikan terhadap Keputusan Pembelian. Suasana Toko tidak memiliki pengaruh terhadap Keputusan Pembelian produk minuman Chatime di Mall Ciputra, Jakarta Barat.
\end{abstract}

Kata Kunci: Kualitas Produk, Kualitas Layanan, Suasana Toko, Keputusan Pembelian

\section{ABSTRACT}

The purpose of this study was to examine the effect of product quality, service quality, and store atmosphere on purchase decision for Chatime drink products at Ciputra Mall, West Jakarta. The sample of this research is 100 Chatime customers at Ciputra Mall. Purposive sampling method was used by distributing online questionnaires which were then processed using PLS-SEM. The results of this study are Product Quality and Service Quality have a positive and significant effect on the Purchase Decision. Store Atmosphere has no effect on the Purchase Decision of Chatime drink products at Ciputra Mall, West Jakarta.

Keywords: Product Quality, Service Quality, Store Atmosphere, Purchase Decision

\section{PENDAHULUAN}

\section{Latar Belakang}

Saat ini, di tengah kesibukan yang padat karena bekerja dan beraktivitas, banyak masyarakat membutuhkan tempat untuk sekedar bersantai menikmati makanan atau minuman bersama teman maupun keluarganya. Banyak pengusaha yang membuka bisnis minuman dikarenakan minuman merupakan kebutuhan pokok setiap orang. Di Indonesia, selain mengonsumsi air mineral, masyarakat juga mengonsumsi teh. Populernya teh membuat banyak pengusaha pada bidang minuman mulai mencoba inovasi baru dalam bisnisnnya. Contoh inovasi teh yang populer adalah teh yang dikombinasikan dengan toping yang biasa dikenal dengan bubble tea. Hal tersebut dapat dilakukan guna menarik pelanggan agar dapat membuat keputusan pembelian untuk produk. Keputusan pembelian menurut Kotler (2003), merupakan keputusan yang diambil konsumen untuk melakukan pembelian suatu produk yang diawali dengan pengenalan kebutuhan, mendapatkan informasi, menilai dan membandingkan beberapa alternatif pembelian yang ada. 
Guna menarik pelanggan penting bagi setiap perusahaan untuk selalu meningkatkan kualitas produknya. Kotler dan Armstrong (2008) mengatakan bahwa kualitas produk adalah keistimewaan produk atau jasa yang bergantung pada kemampuannya untuk memenuhi kebutuhan pelanggan. Selain kualitas produk, kualitas layanan pada setiap perusahaan juga penting bagi perusahaan. Menurut Moha dan Loindong (2016, h.577) "Kualitas layanan adalah segala bentuk aktifitas yang dilakukan oleh perusahaan untuk meningkatkan keunggulan suatu layanan demi memenuhi keinginan dan harapan serta kepuasan pelanggan”. Suasana toko juga memiliki peran penting untuk menarik minat pelanggan. Semakin baik suasana toko maka semakin tertarik juga pelanggan untuk mengunjungi toko. Menurut Risanti dan Khuzaini (2017) suasana toko berhubungan dengan bagaimana para manajer dapat memanipulasi desain bangunan, ruang interior, tata ruang lorong-lorong, tekstur karpet dan dinding, bau, warna, bentuk, dan suara yang di alami para pelanggan. Karenanya penting bagi setiap perusahaan untuk memperhatikan kualitas produk, kualitas layanan, dan suasana toko guna menarik pelanggan untuk membuat keputusan pembelian.

Dilihat dari penelitian terdahulu yang dilakukan oleh Soegoto, Yumi Febiola Merentek (2017) tentang pengaruh Kualitas Produk, Suasana Toko, dan Kualitas Pelayanan Terhadap Keputusan Pembelian Pada KFC Bahu Mall Manado, mendapatkan hasil bahwa kualitas produk, suasana toko, dan kualitas pelayanan memiliki Pengaruh yang positif dan signifikan terhadap keputusan pembelian. Penelitian lain juga dilakukan oleh Risanti dan Khuzaini (2017) tentang Pengaruh Kualitas Layanan, Kualitas Produk, Dan Suasana Toko Terhadap Keputusan Pembelian, mendapatkan hasil bahwa kualitas produk, kualitas layanan, dan suasana toko memiliki pengaruh yang positif dan signifikan terhadap keputusan pembelian. Perbedaan ada pada penelitian yang diakukan Djohansjah dan Pratomo (2017) tentang Pengaruh Store Atmosphere, Kualitas Produk dan Kualitas Layanan terhadap keputusan pembelian di Caturra Espresso menunjukkan bahwa kualitas produk memiliki pengaruh yang positif dan signifikan terhadap keputusan pembelian, sedangkan Store Atmosphere dan kualitas layanan tidak. Karenanya peneliti melakukan penelitian yang berjudul "Pengaruh Kualitas Produk, Kualitas Layanan, Dan Suasana Toko Terhadap Keputusan Pembelian Produk Minuman Chatime di Mall Ciputra, Jakarta Barat.

\section{Kajian Teori}

\section{Keputusan Pembelian}

Menurut Kotler dan Amstrong (2008), keputusan pembelian adalah langkah-langkah dalam proses pengambilan keputusan di mana pelanggan benar-benar membeli. Suharto (2017) menjelaskan bahwa keputusan pembelian adalah perilaku pembelian seseorang dalam menentukan suatu pilihan produk untuk mencapai kepuasan sesuai kebutuhan dan keinginan konsumen yang meliputi pengenalan masalah, pencarian informasi, evaluasi terhadap alternatif pembelian, keputusan pembelian, dan perilaku setelah pembelian. Menurut Oscar dan Keni (2019), Keputusan pembelian merupakan pertimbangan-pertimbangan yang dilakukan oleh konsumen dalam menyeleksi suatu produk sebelum melakukan pembelian.

\section{Kualitas Produk}

Menurut Lasander (2013) Kualitas produk adalah keseluruhan kualitas atau keunggulan suatu produk atau jasa layanan berkaitan dengan apa yang diharapkan oleh pelanggan. Lubis (2015) mengungkapkan bahwa kualitas produk merupakan upaya yang dilakukan perusahaan dalam memberikan kepuasan bagi konsumen. Kotler dan Armstrong (2008) mengatakan bahwa kualitas produk adalah keistimewaan produk atau jasa yang bergantung pada kemampuannya untuk memenuhi kebutuhan pelanggan. 


\section{Kualitas Layanan}

Nursanti dan Herlina (2012) mengungkapkan bahwa kualitas layanan adalah kinerja yang mengarah pada mutu yang diharapkan dari yang ditawarkan secara lebih mendalam karena manfaat besar yang dihasilkan dari pelayanan, yang dapat meningkatkan intensitas pembelian dan loyalitas pelanggan. Menurut Moha dan Loindong (2016) Kualitas layanan adalah segala bentuk aktifitas yang dilakukan oleh perusahaan untuk meningkatkan keunggulan suatu layanan demi memenuhi keinginan dan harapan serta kepuasan pelanggan.

\section{Suasana Toko}

Suharto (2017) mengungkapkan bahwa suasana toko adalah suasana yang diciptakan oleh toko sehingga mempengaruhi emosi pembeli yang menyebabkan pembelian. Menurut Isnandari dan Sunarti (2018) Suasana toko adalah suatu kombinasi berbagai karakteristik suatu restoran yang kemudian diharapkan dapat membentuk citra restoran, meliputi arsitektur, tata ruang, papan tanda dan pajangan, pewarnaan, pencahayaan, suhu udara, suasana, dan aroma yang akan mempengaruhi ketertarikan konsumen hingga perilaku pembelian oleh konsumen.

\section{Kaitan antara Kualitas Produk dengan Keputusan Pembelian}

Kodu (2012) meneliti industri otomotif di Manado. Dalam penelitiannya terdapat hasil bahwa kualitas produk memiliki pengaruh yang postif terhadap keputusan pembelian mobil Toyota Avanza di Manado. Penelitian yang sejalan dilakukan oleh Sejati (2016) yang meneliti tentang restoran di Surabaya. Dalam penelitiannya disebutkan bahwa kualitas produk memilik pengaruh yang positif terhadap keputusan pembelian Starbucks di Surabaya. Hal tersebut juga didukung dengan hasil penelitian yang dilakukan oleh Aminudin (2015) yang mendapatkan hasil bahwa kualitas produk memiliki pengaruh yang positif terhadap keputusan pembelian pada KFC Mega Mas Manado.

\section{Kaitan antara Kualitas Layanan dengan Keputusan Pembelian}

Firdausy dan Idawati (2017) dalam penelitian menyebutkan bahwa kualitas layanan memiliki pengaruh yang positif dan signifikan terhadap keputusan pembelian. Penelitian lain dilakukan oleh Rachman dan Suryoko (2017) tentang industri kuliner. Pada penelitiannya disebutkan hasil bahwa kualitas layanan memiliki pengaruh yang positif terhadap keputusan pembelian pada Rumah Makan Wajan Mas Kudus. Hasil tersebut didukung oleh Sriyanto dan Utami (2016) yang melakukan penelitian tentang pelanggan otomotif. Dalam penelitiannya terdapat hasil bahwa kualitas layanan memiliki pengaruh yang signifikan terhadap keputusan pembelian pada produkk Dadone di PT. Super Safe Sejati Jakarta.

\section{Kaitan antara Suasana Toko dengan Keputusan Pembelian}

Febriatmoko (2018) melakukan penelitian pada industri ritel. Hasil yang didapat adalah suasana toko memiliki pengaruh positif pada keputusan pembelian pada Palapa Toserba di Surabaya. Penelitian lain dilakukan oleh Wahyuningtias dan Wahyuati (2017) di Surabaya. Dalam penelitian tersebut terdapat hasil bahwa suasana toko memiliki hubungan yang signifikan terhadap keputusan pembelian. Isnandari dan Sunarti (2018) meneliti pelanggan yang mengkonsumsi kopi di Malang. Penelitiannya menyebutkan hasil bahwa suasana toko mempunyai pengaruh signifikan pada keputusan pembelian pada Java Dancer Coffee di Malang. 


\section{Hipotesis}

$\mathrm{H}_{1}$ : Kualitas Produk berpengaruh positif terhadap Keputusan Pembelian produk minuman Chatime di Mall Ciputra Jakarta Barat

$\mathrm{H}_{2}$ : Kualitas Layanan berpengaruh positif terhadap Keputusan Pembelian produk minuman Chatime di Mall Ciputra Jakarta Barat

$\mathrm{H}_{3}$ : Suasana Toko berpengaruh positif terhadap Keputusan Pembelian produk minuman Chatime di Mall Ciputra Jakarta Barat

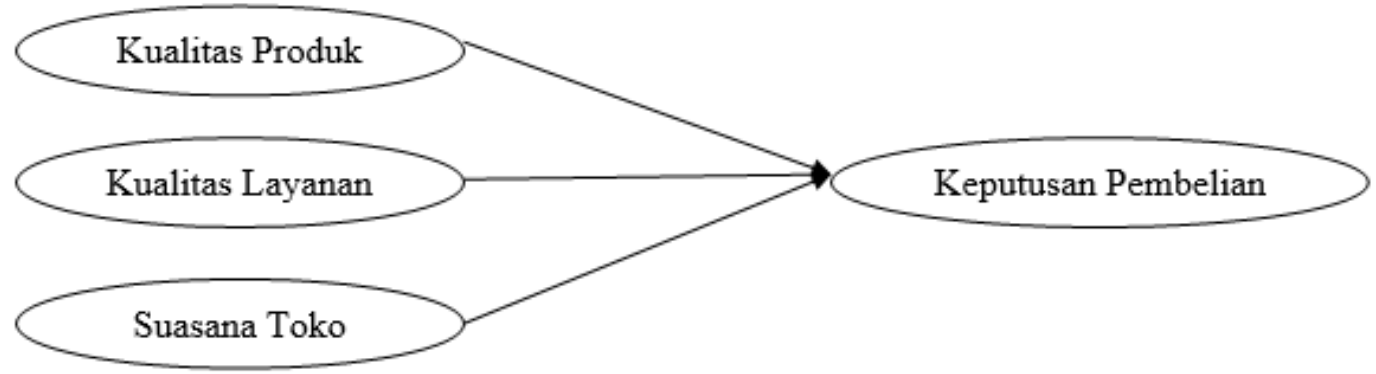

Gambar 1. Model penelitian

\section{METODE PENELITIAN}

Penelitian ini menggunakan desain penelitian deskriptif. Pada penelitian ini populasi yang digunakan adalah yang membeli Chatime di Mall Ciputra minimal dua kali dalam satu bulan terakhir. Teknik pengambilan sampel yang digunakan adalah purposive sampling, dengan jumlah sampel 100 orang responden. Data yang ada di analisis dengan menggunakan software smartPLS dengan teknik analisis data structural equation model (SEM).

\section{HASIL DAN PEMBAHASAN}

Dalam penelitian ini, pengujian validitas data diukur dengan menggunakan nilai convergent validitty dan discriminant validity, dimana validitas konvergen dianggap valid apabila nilai average variance extracted (AVE) bernilai lebih dari 0,5 . Dalam penelitian ini, nilai average variance extracted (AVE) (Tabel 1) telah sesuai dengan syaratnya. Validitas diskriminan dalam penelitian ini dilihat dari pengukuran Fornell-Lacker (Tabel 2). Dalam penelitian ini, semua variabel telah memenuhi ketentuan validitas diskriminan karena memiliki nilai lebih besar daripada konstruk lainnya.

Tabel 1. Hasil Uji Average Variance Extracted (AVE)

\begin{tabular}{|c|c|}
\hline Variabel & Average Variance Extracted \\
\hline Keputusan Pembelian & 0,636 \\
\hline Kualitas Layanan & 0,530 \\
\hline Kualitas Produk & 0,501 \\
\hline Suasanan Toko & 0,540 \\
\hline
\end{tabular}

Tabel 2. Hasil Uji Fornell-Lacker

\begin{tabular}{|c|c|c|c|c|}
\hline Variabel & Keputusan Pembelian & $\begin{array}{c}\text { Kualitas } \\
\text { Layanan }\end{array}$ & Kualitas Produk & Suasana Toko \\
\hline Keputusan Pembelian & $\mathbf{0 , 7 9 7}$ & & & \\
\hline Kualitas Layanan & 0,627 & $\mathbf{0 , 7 2 8}$ & & \\
\hline Kualitas Produk & 0,601 & 0,614 & $\mathbf{0 , 7 0 8}$ & \\
\hline Suasana Toko & 0,545 & 0,672 & 0,697 & $\mathbf{0 , 7 3 5}$ \\
\hline
\end{tabular}


Pengujian reliabilitas konsistensi internal dapat dilihat dari nilai composite reliability (Tabel 3). Pada penelitian ini, semua variabel memiliki nilai $>0,70$ yang artinya variabel tersebut telah memenuhi syarat uji konsistensi internal.

Tabel 3. Hasil Composite Reliability

\begin{tabular}{|c|c|}
\hline Variabel & Composite Reliability \\
\hline Keputusan Pembelian & 0,940 \\
\hline Kualitas Layanan & 0,955 \\
\hline Kualitas Produk & 0,933 \\
\hline Suasana Toko & 0,961 \\
\hline
\end{tabular}

Selanjutnya, dilakukan analisis $R$-square yang menujukkan nilai $R$-square sebesar 0,469 yang menjelaskan bahwa sebesar 46,9\% variasi variabel keputusan pembelian dapat dijelaskan oleh variabel kualitas produk, kualitas layanan, dan suasana toko. Sisanya sebesar 53,1\% dapat dijelaskan oleh variabel yang tidak diteliti dalam penelitian ini. Pada hasil analisis Predictive Relevance $\left(\mathrm{Q}^{2}\right)$ menjelaskan bahwa hubungan konstruk variabel-variabel yang diteliti dalam penelitian ini di anggap relevan karena memiliki nilai $\mathrm{Q}^{2}$ lebih besar dari $0(>0)$. Dan dari uji Effect Size (Tabel 4) didapatkan hasil bahwa Kualitas Layanan, Kualitas Produk, daan Suasana Toko memiliki pengaruh yang kecil terhadap keputusan pembelian.

Tabel 4. Hasil Effect Size

\begin{tabular}{|c|c|}
\hline Variabel & Keputusan Pembelian \\
\hline Kualitas Layanan & 0,146 \\
\hline Kualitas Produk & 0,091 \\
\hline Suasana Toko & 0,003 \\
\hline
\end{tabular}

Berdasarkan pengujian indikator formatif, uji multikolinearitas pada dimensi kualitas produk, kualitas layanan, dan suasana toko memiliki nilai VIF kurang dari 5 yang artinya tidak terdapat multikolinearitas. Dan pada pengujian Sign of Weight, dapat dilihat bahwa $t$-statistic dan $p$-value pada dimensi kualitas produk, kualitas layanan, dan suasana toko adalah signifikan.

Tabel 5. Hasil Uji Sign of Weight Kualitas Produk

\begin{tabular}{|c|c|c|}
\hline Dimensi & t-statistic & p-value \\
\hline Estethic & 12,877 & 0,000 \\
\hline Features & 10,511 & 0,000 \\
\hline Performance & 11,381 & 0,000 \\
\hline Durability & 9,161 & 0,000 \\
\hline Conformance & 14,243 & 0,000 \\
\hline Reliability & 11,342 & 0,000 \\
\hline Percived quality & 11,605 & 0,000 \\
\hline
\end{tabular}

Tabel 6. Hasil Uji Sign of Weight Kualitas Layanan

\begin{tabular}{|c|c|c|}
\hline Dimensi & t-statistic & p-value \\
\hline Tangible & 13,941 & 0,000 \\
\hline Assurance & 13,399 & 0,000 \\
\hline Reliability & 12,807 & 0,000 \\
\hline Responsiveness & 18,165 & 0,000 \\
\hline Empathy & 12,621 & 0,000 \\
\hline
\end{tabular}


Tabel 7. Hasil Uji Sign of Weight Suasana Toko

\begin{tabular}{|c|c|c|}
\hline Dimensi & $\boldsymbol{t}$-statistic & $\boldsymbol{p}$-value \\
\hline Cleanliness & 13,277 & 0,000 \\
\hline Music & 13,823 & 0,000 \\
\hline Scent & 9,909 & 0,000 \\
\hline Temperature & 11,461 & 0,000 \\
\hline Lighting & 13,461 & 0,000 \\
\hline Color & 12,932 & 0,000 \\
\hline Display/layout & 14,083 & 0,000 \\
\hline
\end{tabular}

Pada pengujian Path Coefficient (Tabel 8) didapatkan hasil bahwa Kualitas Layanan dan Kualitas Produk memberi pengaruh kuat dan positif terhadap keputusan pembelian. Sedangkan Suasana toko memberi pengaruh negatif yang lemah terhadap keputusan pembelian.

Tabel 8. Hasil Path Coefficient

\begin{tabular}{|c|c|c|c|}
\hline & Path Coefficient & t-Statistic & P-Values \\
\hline Kualitas Layanan $\rightarrow$ Keputusan Pembelian & 0,391 & 3,181 & 0,002 \\
\hline Kualitas Produk $\rightarrow$ Keputusan Pembelian & 0,318 & 2,576 & 0,010 \\
\hline Suasana Toko $\rightarrow$ Keputusan Pembelian & 0,061 & 0,441 & 0,659 \\
\hline
\end{tabular}

Berdasarkan hasil uji hipotesis pertama, kualitas produk memiliki pengaruh yang positif signifikan terhadap keputusan pembelian di Chatime Mall Ciputra. Hal ini dapat dilihat pada Tabel 8 yang menunjukan nilai $t$-statistic sebesar 2,576 lebih besar dari 1,96 dan $p$-value sebesar 0,010, dimana nilai tersebut lebih kecil dari $0,05(<0,05)$, maka dapat dijelaskan bahwa hipotesis $\mathrm{H}_{1}$ tidak ditolak. Berdasarkan hasil uji hipotesis kedua, kualitas layanan memiliki pengaruh yang positif dan signifikan terhadap keputusan pembelian di Chatime Mall Ciputra. Hal ini dapat dilihat pada Tabel 8 yang menunjukan nilai $t$-statistic sebesar 3,181 lebih besar dari 1,96 dan nilai $p$-value sebesar 0,002 , dimana nilai tersebut lebih kecil dari $0,05(<0,05)$, maka dapat dijelaskan bahwa hipotesis $\mathrm{H}_{2}$ tidak ditolak. Berdasarkan hasil uji hipotesis ketiga, suasana toko tidak memiliki pengaruh terhadap keputusan pembelian di Chatime Mall Ciputra. Hal ini dapat dilihat pada Tabel 8 yang menunjukan nilai $t$-statistic sebesar 0,441 kurang dari 1,96 dan nilai $p$ value sebesar 0,659, dimana nilai tersebut lebih besar dari 0,05 $(<0,05)$, maka dapat dijelaskan bahwa hipotesis $\mathrm{H}_{3}$ ditolak. Artinya suasana toko di Chatime bukan merupakan salah satu faktor yang membuat pelanggan melakukan keputusan pembelian. Karena kebanyakan pelanggan membeli Chatime untuk diminum di jalan atau dibawa pulang, sehingga suasana toko tidak menjadi faktor yang penting untuk menarik pelanggan membeli produk.

\section{Diskusi}

Berdasarkan hasil uji hipotesis pertama, kualitas produk memiliki pengaruh yang positif signifikan terhadap keputusan pembelian Chatime di Mall Ciputra. Hal ini dapat dilihat dari nilai $t$-statistic sebesar 2,576 lebih besar dari 1,96 dan p-value sebesar 0,010, dimana nilai tersebut lebih besar dari $0,05(<0,05)$, maka dapat dijelaskan bahwa hipotesis $\mathrm{H}_{1}$ tidak ditolak. Hal ini sejalan dengan penelitian sebelumnya oleh Sejati (2016) yang meneliti tentang Pengaruh Kualitas Produk, Kualitas Pelayanan, dan Harga Terhadap Keputusan Pembelian Pada Starbucks menunjukan bahwa kualitas produk berpengaruh secara signifikan dan positif terhadap keputusan pembelian. Penelitian lain oleh Anwar (2015) yang menunjukan hasil bahwa kualitas produk berpengaruh secara signifikan dan positif terhadap keputusan pembelian juga sejalan dengan penelitian ini. Selanjutnya, penelitian yang dilakukan oleh Ong dan Sugiharto (2013) tentang Pengaruh Citra, Diferensiasi, Kualitas Produk, Dan Harga Terhadap Keputusan Pembelian Pelanggan di Cincau Station Grand City, Surabaya menunjukkan hasil bahwa kualitas 
produk berpengaruh secara signifikan dan positif terhadap keputusan pembelian, penelitian tersebut juga sejalan dengan penelitian ini.

Berdasarkan hasil uji hipotesis kedua, kualitas layanan memiliki pengaruh yang positif dan signifikan, dengan efek yang kecil terhadap keputusan pembelian Chatime di Mall Ciputra, maka dapat dijelaskan bahwa $\mathrm{H}_{2}$ tidak ditolak. Hal ini sesuai dengan penelitian sebelumnya yang dilakukan oleh Suryoko (2017) tentang Pengaruh Kualitas Pelayanan dan Harga Terhadap Keputusan Pembelian (Studi Kasus Pada Rumah Makan Wajan Mas Kudus) menyatakan bahwa kualitas pelayanan, dan harga berpengaruh signifikan dan positif terhadap keputusan pembelian. Penelitian yang dilakukan oleh Luthfianto (2017) tentang Pengaruh Kualitas Layanan dan Gaya Hidup Terhadap Keputusan Pembelian Cafe Jalan Korea mendapatkan hasil bahwa kualitas layanan memiliki pengaruh yang positif dan signifikan terhadap keputusan pembelian, hal tersebut sejalan dengan penelitian ini. Kemudian, penelitian yang dilakukan Djohansjah dan Pratomo (2017) tentang Pengaruh Store Atmosphere, Kualitas Produk dan Kualitas Layanan terhadap keputusan pembelian di Caturra Espresso menunjukkan bahwa kualitas layanan memiliki pengaruh yang positif dan signifikan terhadap keputusan pembelian, penelitian tersebut sesuai dengan penelitian ini.

Berdasarkan hasil uji hipotesis ketiga, suasana toko tidak memiliki pengaruh terhadap keputusan pembelian di Chatime Mall Ciputra, maka dapat dijelaskan bahwa $\mathrm{H}_{3}$ ditolak. Hal ini tidak sejalan dengan penelitian sebelumnya oleh Febriatmoko (2018) yang meneliti tentang Pengaruh Store Atmosphere, dan Harga Terhadap Keputusan Pembelian (Studi Pada Konsumen Palapa Toserba Surabaya) yang mendapatkan hasil bahwa Store Atmosphere berpengaruh signifikan terhadap keputusan pembelian. Penelitian lain dilakukan oleh Diawan (2016) yang meneliti tentang The Influence Of Store Atmosphere On Purchase Decision And It's Impact On Customer's Satisfaction menunjukkan bahwa suasana toko memiliki pengaruh yang positif dan signifikan terhadap keputusan pembelian, hal tersebut tidak sejalan dengan penelitian ini. Selain itu, penelitian lain dilakukan oleh Suharto (2017) tentang Pengaruh Gaya Hidup, Suasana Toko dan Kualitas Pelayanan Terhadap Keputusan Pembelian Pada Giggle Box Cafe \& Resto Semarang menunjukkan bahwa suasana toko memiliki pengaruh yang positif dan signifikan terhadap keputusan pembelian. Penelitian ini tidak sejalan dengan penelitian sebelumnya, yang artinya suasana toko di Chatime bukan merupakan salah satu faktor yang membuat pelanggan melakukan keputusan pembelian. Karena kebanyakan pelanggan membeli Chatime untuk diminum di jalan atau dibawa pulang, sehingga suasana toko tidak menjadi faktor yang penting untuk menarik pelanggan membeli produk.

\section{KESIMPULAN DAN SARAN}

Berdasarkan hasil uji, hasil analisis, dan pembahasan yang telah dijelaskan, maka kesimpulan penelitian ini adalah sebagai berikut:

1. Kualitas produk memiliki pengaruh yang positif dan signifikan terhadap keputusan pembelian produk minuman Chatime di Mall Ciputra, Jakarta Barat.

2. Kualitas Layanan memiliki pengaruh yang positif dan signifikan terhadap keputusan pembelian produk minuman Chatime di Mall Ciputra, Jakarta Barat.

3. Suasana Toko tidak memiliki pengaruh yang positif dan signifikan terhadap keputusan pembelian produk minuman Chatime di Mall Ciputra, Jakarta Barat. 


\section{REFERENSI}

Aminnudin, L. (2015). Pengaruh Kualitas Produk, Pormosi, dan Store Atmosfir Terhadap Keputusan Pembelian Konsumen pada KFC Mega Mas Manado. Jurnal Berkala Ilmiah Efisiensi, 15(5), 703-715.

Anwar, I. (2015). Pengaruh Harga Dan Kualitas Produk Terhadap Keputusan Pembelian. Jurnal Ilmu Dan Riset Manajemen, 4(12). https://doi.org/10.47335/ema.v4i1.34

Diawan, N. S., Kusumawati, A., \& Mawardi, M. K. (2016). The Influance Of Store Atmosphere On Purchase Decision And It's Impact On Customer's Satisfaction ( Case study on Indomaret Customers JL . Raya Tlogomas No . 37 , Malang ). Jurnal Administrasi Bisnis (JAB), 30(37), 8-16.

Djohansjah, C., \& Pratomo, C. V. (2017). Analisis pengaruh store atmosphere, kualitas produk dan kualitas pelayanan terhadap keputusan pembelian di caturra espresso. Jurnal Hospitality Dan Manajemen Jasa, 5(2), 404-418.

Febriatmoko, A. (2018). Pengaruh Store Atmosphere dan harga terhadap keputusan pembelian (studi pada konsumen palapa toserba Surabaya). Jurnal Ilmu Manajemen, 6(4), 445-451.

Firdausy, C. M. \& Rani Idawati. (2017). Effect of Service Quality, Price, and Promotion on Customers Purchase Decision of Treveloka Online Airline Tickets In Jakarta, Indonesia. International Journal of Management Science and Business Administration. 3. 42-49.

Isnandari, A., \& Sunarti. (2018). Pengaruh Kualitas Produk, Store Atmosphere, Dan Harga Terhadap Kepuasan Konsumen. Jurnal Administrasi Bisnis, 60(3), 104-111.

Kodu, S. (2013). Harga, kualitas produk dan kualitas pelayanan pengaruhnya terhadap keputusan pembelian mobil Toyota Avanza. Jurnal EMBA, 1(3), 1251-1259.

Kotler, P. (2003). Marketing management. New Jersey: Pearson Education International

Kotler, P dan G, Armstrong. 2008. Prisnip-prinsip Pemasaran. Edisi 12. Erlangga. Jakarta

Lasander, C. (2013). Citra Merek, Kualitas Produk, Dan Promosi Pengaruhnya Terhadap Kepuasan Konsumen Pada Makanan Tradisional. Jurnal Riset Ekonomi, Manajemen, Bisnis Dan Akuntansi, 1(3), 284-293. https://doi.org/10.35794/emba.v1i3.2024

Lubis. (2015). Pengaruh Harga dan Kualitas Produk terhadap Keputusan Pembelian Surat Kabar pada PT. Suara Barisan Hijau Harian Orbit Medan. 16(02), 1-11.

Luthfianto, D. (2017). Pengaruh kualitas layanan dan Gaya Hidup Terhadap Keputusan Pembelian Cafe Jalan Korea. Jurnal Ekonomi Bisnis, 22(1), 14-25.

Merentek, Y. F., Lapian, J., \& Soegoto, A. S. (2017). Pengaruh Kualitas Produk, Suasana Toko Dan Kualitas Pelayanan Terhadap Keputusan Pembelian Pada KFC Bahu Mall Manado. Jurnal EMBA, 5(2), 2839-2847.

Moha, S., \& Loindong, S. (2016). Analisis Kualitas Pelayanan Dan Fasilitas Terhadap Kepuasan Konsumen Pada Hotel Yuta Di Kota Manado. Jurnal EMBA, 4(1), 575-584.

Nursanti, T. D., \& Herlina, H. (2012). Analisis Pengaruh Suasana Toko, Variasi Merchandise, dan Kualitas Pelayanan terhadap Keputusan Pembelian Aksesoris Gadget: Studi Kasus Gerai Wellcommshop Mal Citraland. Binus Business Review, 3(1), 356.

Ong, I. A., \& Sugiharto, S. (2013). Analisa Pengaruh Strategi Diferensiasi, Citra Merek, Kualitas Produk Dan Harga Terhadap Keputusan Pembelian Pelanggan Di Cincau Station Surabaya. Manajemen Pemasaran, 1(2), 1-11.

Oscar, Y., \& Keni. (2019). Pengaruh Brand Image, Peresepsi Harga, dan Service Quality terhadap Keputusan Pembelian. Jurnal Muara Ilmu Ekonomi dan Bisnis. 3(1), 20-28. http://dx.doi.org/10.24912/jmieb.v3i1.3300

Rachman, D. A., \& Suryoko, S. (2017). Pengaruh Kualitas Pelayanan Dan Harga Terhadap Keputusan Pembelian (Studi Kasus Pada Rumah Makan Wajan Mas Kudus). Diponegoro Journal of Social and Political Science, 1-8. 
Risanti, A., \& Khuzaini. (2017). Pengaruh kualitas pelayanan, kualitas produk, dan store atmosphere terhadap keputusan pembelian. Jurnal Ilmu dan Riset Manajemen, 6(4), 1-17.

Sejati, B. S. A., \& Yahya. (2016). Pengaruh kualitas produk, kualitas pelayanan, dan harga terhadap keputusan pembelian pada Starbucks. Jurnal Ilmu dan Riset Manajemen, 5(3), 119

Sholihat, A. (2019). Pengaruh Promosi Penjualan Dan Kualitas Pelayanan Terhadap Keputusan Pembelian Di Krema Koffie. Journal of Chemical Information and Modeling, 53(9), 16891699.

Sriyanto, A., \& Utami, D. A. (2016). Pengaruh Kualitas Produk, Citra Merek dan Kualitas Layanan terhadap Keputusan Pembelian Produk Dadone di Jakarta. Ekonomika Dan Manajemen, 5(2), 163-175.

Suharto, G. P. (2017). Pengaruh Gaya Hidup, Suasana Toko Dan Kualitas Pelayanan Terhadap Keputusan Pembelian Pada Giggle Box Cafe \& Resto Semarang. Jurnal Ilmu Administrasi Bisnis, 6(024), 118-129.

Wahyuningtias, R., \& Wahyuati. A. (2017). Pengaruh kualitas produk, harga dan store atmosphere terhadap keputusan pembelian. Jurnal Ilmu dan Riset Manajemen, 6(3), 1-18 